\title{
The Surrounding Regions of Iran and the Regionalism in Foreign Policy of Islamic Republic of Iran
}

\author{
Fahimeh Sardashti ${ }^{1} \&$ Hamid Ahmadi ${ }^{1}$ \\ ${ }^{1}$ Department of International Relations, College of Law and Political Science, Tehran Science and Research \\ Branch, Islamic Azad university, Tehran, Iran \\ Correspondence: Fahimeh Sardashti, Department of International Relations, College of Law and Political \\ Science, Tehran Science and Research Branch, Islamic Azad university, Tehran, Iran. E-mail: \\ Fa.sardashti@yahoo.com
}

Received: January 21, 2016 Accepted: February 16, 2016 Online Published: March 31, 2016

doi:10.5539/jpl.v9n2p125 URL: http://dx.doi.org/10.5539/jpl.v9n2p125

\begin{abstract}
In addition to internal conditions, surrounding environment of any country provide opportunities as well as limitations within the process of policy making particularly in terms of foreign policy. It seems axiomatic that overlooking the surrounding regions within the process of policy making can lead to irrecoverable damages on the country's interests. In the present study it has been attempted to examine the features and abilities of surrounding regions of Iran as well as answering the question that which regions have advantage and priority to provide national goals and foreign policy of Iran has been presented at the conclusion of the hypothesis that Northern and Eastern regions surrounding the country (ECO zone) because of the presence cultural, language and religious similarities hold higher rate of capacity in order to provide foreign policy goals.
\end{abstract}

Keywords: surrounding regions, foreign policy, southern area (Persian Gulf and Arabian Peninsula). Eastern area (Indian Subcontinent and Afghanistan), Northern area (Middle East and Caucus)

\section{Introduction}

In addition to internal conditions, surrounding environment of any country provide opportunities as well as limitations within the process of policy making particularly in terms of foreign policy. However, nowadays it has been substantiated to all states that if they are interested in developing the economy of the country they have to enter the regional arrangements in order to enter the world economy. Easier access to the developed states markets, the possibility of specialized exports of the developing countries and the expansion of their export capacities, more convenient technology exchange possibility, technical knowledge and experiences among developing states as a tool for better engagement with that of world economy are among the advantages of interactions at regional level (Soleiman poor and Daman pak, 2009, 82). By emphasizing the fact that the similar point in terms of the definitions of regionalism is that the particular region has the highest efficiency for the fulfillment of available parameters and undoubtedly the parameters present in this perspective are profit-oriented criteria (Simber, 2005, 134). In the present study it has been attempted to examine the features and abilities of surrounding regions of Iran as well as answering the question that which regions have advantage and priority to provide national goals and foreign policy of Iran? In this respect in the following parts of the present study in order to do a more comprehensive study of the aforementioned areas the focus is on highlighting the positive and negative aspects of surrounding regions in relation with that of foreign policy of Iran.

\section{Southern Area: Persian Gulf and Arabian Peninsula}

Iran being encircled by land borders in the North, East, and West has access to the free sea only through the South. Therefore, this is a country whose only window towards the world is open to Persian Gulf as a quasi-encircled land (Ghasemi, 2003, 39). This area because of having special economic, communicational, strategic and cultural values over the history has been highly considered by the great powers and its dominance has lead to the change of power balance among powerful states. These values are as follows: a: Communicational role and value among three continents of Africa, Asia, and Europe which was more significant in the past and today has a role of providing transportation system between Indian, pacific ocean and Red and Mediterranean sea to transport goods and oil. b) Energetic value which as the biggest oil source of the world $65 / 5$ percent of the oil reserves of the world is located in it and besides that $27 / 7$ percent of the world natural gas 
reserves c) Economic value which has been acquired by the oil revenues along with large number of consumer population has made Persian Gulf as the hub of attention of exporters of arms, industrial goods and non-industrial good of the world d) Geo-politic value of the area which is caused by the geographic position of the Persian Gulf in the world. Persian Gulf and Strait of Hormuz according to world geo-strategic and geo-politic views has been located in the marginal area of the central part which provides land and sea connection e) finally the cultural value, which is because of the centrality of the appearance of the Islam religion and the Qibla of the Muslims in this area. Control and dominance over this centrality means control over a large part of the world from the west of the Africa to the East of the world which have special economic, communicational and strategic values. It's worth mentioning that the most significant geographic communication corridor of the Persian Gulf with that of the outside world and vice versa is the strait of Hormuz (Hafez Nia 1990, 44-46). Ira, Iraq, Saudi Arabia, Qatar, Kuwait, United Arab Emirates, Bahrain, Oman are the eight countries which have been located in the Persian Gulf and Iran is the only Non-Arab country in the region. The most important regional organization in Persian Gulf is the Gulf Cooperation Council that except for Iran and Iraq the other aforementioned six countries have become part of it.

\section{Political and Cultural and Economic Importance of the Southern Area}

A) Political. Three powerful states of the region are Iran Saudi Arabia and Iraq that each of them have their or directions (Rathmell, 2003) and since 1960 majority of the relation among them involves rivalry and dispute for overtaking at regional level and from that time onward this rivalry has lead to alignment of the forces in the region (Azimi, 2001). Islamic Republic of Iran is the most important player in the region. The armed forces of this country constitute the most powerful forces of the region. Even in terms of population the number of the population of Iran is more than all of the other Persian Gulf states and from geographic perspective all of the Northern borders of the Persian Gulf belong to Iran. Similarly the possession of the northern side of the Strait of Hormuz and the presence of several islands at the mouth of this Strait it has provides an opportunity for Iran to take control of the area (Taromi, 2007, 94). The other power of the region that is Saudi Arabia has always tired to make ties with one of the other two powers of the region in fear of possible threats from a third power (Iran and Iraq). For this reason, before the Islamic Republic of Iran in line with Iran tied to neutralize the ideological threats of Iraq and after the victory of the Islamic revolution in Iran and the start of the eight-year war confronted with Iran and supported Iraq. But by the occupation of Kuwait the Saudi policy took a different direction which was not based on the alliance or cooperation with none of these two countries but from this time Saudi Arabia in alliance with the west practiced the "dual containment" policy (Azimi, 2006). Iraq has always tied to earn a special position among Arabic countries of the Persian Gulf region. For this purpose and before the fall of Saddam who tries to get the dominance over the Arab world tries to practice his Islamic and Arabic views by besieging the support and protection in the region (Inbar and Bachevich 2003,30). The ultimate purpose of Saddam in fight against Iran and the occupation of Kuwait were to get power in the region but the occupation of Kuwait in contrast to that of war against Iran faced the reaction of the international system and lead to the occupation of Iraq by the coalition forces. Even now the volatilities caused by this situation have created insecurity in western borders of Islamic Republic of Iran.

All members of the Persian Gulf cooperation council have border disputes with at least one of the members of the council or the other neighboring countries. In this respect, border disputes of Qatar and Saudi Arabia in 1992 and 1994 and Saudi Arabia and Yemen border disputes and Iraq and Kuwait disputes over Bubian and Varbe and Ommalghasr islands (Maleki, 2001, 117) and ultimately, border disputes between the UAE and Islamic Republic of Iran over the triple islands of Greater Tunb and smaller Tunb and Abumusa are considerable. in this respect the only case which has been unilaterally supported by the Persian Gulf cooperation council is the difference of opinion in between the UAE and Islamic Republic of Iran. The council in the final statement of its $21^{\text {st }}$ summit in addition to supporting the position of Iran in the case of triple islands has condemned Iran in the strongest way and has appointed a mission for the coming summit of the member foreign ministers of the council to make use of all peaceful means under their power to obtain the legal rights of the UAE in terms of the possession of triple islands (Maleki, 2001, 120). in the continuation of these issues we observe that in March of 2013 Saudi Arabia and Bahrain are trying to establish a union the same as that of European Union and the prince ben Salman the prime minister of Bahrain stated that: the choice of establishing Persian Gulf Union is very essential and also asserted the readiness of the Arab states of the Persian Gulf to reinforce their security and diplomatic relations with each other to confront issues such as Arabic Spring and disputes with Iran (fa/news/1893/www.Karmandnews.ir).

But it should be mentioned that the measures taken by Iran have lead to such reactions by the Arab countries of the Persian Gulf cooperation council. the attempts made by Iran to achieve nuclear technology is an instance in 
this respect. despite the fact that Iran has repeatedly stated that the purpose of Iran is peaceful but taking such a policy by Iran has caused panic among the countries of the region. Military power and its development is another parameter which leads to regional power. Although most of the regional countries of the Persian Gulf cooperation council have become militarily reinforced by the United States but having nuclear power which Iran denies it can panic any country this issue gets more important by the fact that the country which has tried to achieve nuclear technology claims the Islamic world leadership and exporting the Islamic revolution. Despite the strategic significance of the Persian Gulf the regional states including island states have not made any attempt to develop marine capabilities to attend long-distance destinations away from their coasts. After the purchase of Kilo type submarine (Killo Class) by Iran from Soviet/Russia many of the regional players of the region looked at Iran a look of distrust and suspicion to the actions done by Iran and considered it as a country which intends to expand its ambitious plans to achieve marine power beyond the surrounding coasts and Strait of Hormuz (Lotfian, 2007, 13).

These activities by Iran have lead to the panic and fear among regional states so that some of the regional states tried to establish relations with Israel. According to this report from Times Israel Netanyahu in his recent speech has stated that the common concern in terms of the nuclear program of Iran has convinced many of the Arab neighbors that Israel is not their enemy and this is an opportunity to establish relations with them (www.entekhab.ir/fa/news/210525). Despite the fact that Saudi Arabia and Israel don't have official relations and Riyadh has not officially recognized Israel but these two countries have had five secret meetings after 2014 to discuss Iran and the rise of power of Iran (Bendder 2015). And the representatives of Israel and Saudi Arabia met each other in a meeting in Washington in terms of the threats of Iran. At this meting which was planned and run by the research center of the foreign relations council in Washington the representatives of Israel and Saudi Arabia revealed that over the last 17 months in terms of the ways of confronting the threat of Iran in the region have discussed with each other. These dialogues have occurred in Italy, Czech Republic and India (http://fa.rfi.fr/0150605). At the present time and after the negotiations between Iran and 5+1 the concerns of the regional states have risen in another way. Particularly from Saudi perspective the nuclear agreement between Iran and 5+1means that on the one hand the economic situation of Iran would improve and on the other hand the capacity of creating nuclear arms get facilitated. As a result the improvement would lead to the development of Iran and its allies in the region. Since Israel is the only country in the region which possess nuclear technology this would secure the regional hegemony of the Israel. It is evident that the $5+1$ nuclear agreement with Iran would end up this exclusion (http://www.aljazeera.com/news/2015/04/saudi-arabia-israel-oppose-iran-nuclear-deal-150401061906177.html).

B) Economic. From economic vantage point Persian Gulf is of high significance in policy making of Islamic Republic of Iran. This significance can be recapped in the following four items: First: At the present time the economy of Iran is highly under the influence and pressure of International sanctions system. Since the major resource of state revenues come from the oil sale imposing sanction to restrain oil sale by other countries and receiving the oil sale payments have troubled people and the officials in Iran. The attention towards the Persian Gulf region by the statesmen has reduced the negative impact of these sanctions to a large extent. The location of the Strait of Hormuz in Persian Gulf which is between Iran and Oman which is the second most commuted strait in the world and that the major control of the strait is under the control of Iran is among the advantages which has been able to assist Iran in this respect. Every day around 16/5-17 million barrels of raw oil (est 2006) which equals $40 \%$ of the total oil tankers transportation and around $25 \%$ of the global supply passes through this strait. most of this oil is transported to the markets of Asia, United States of America and Europe and $75 \%$ of the raw oil of Japan passes through this passage. According to the published statics the oil of the eight countries of the Persian Gulf pass through this corridor and also $50 \%$ of the goods exchange of these countries pass through the Strait of Hormuz. Economic experts believe that in case of blockage of this strait the global oil market would face a 16/5-20 million barrel shortage of oil and the price of the oil would rise up to twice the current price of the oil (Tabnak 2012, news code 210777). The alternative land passages which include the East West Saudi pipeline in case of readiness for operation would transport less than half of the amount but by the assumption of total transport of oil by land would incur costs for constructing pipeline, pumping oil and maintenance and securing the safety of the them these lines regardless of the long time required for their preparation any blockage of the Strait of Hormuz can lead to considerable rise of oil price. By this description the economic pulse of many industrial countries would be under the control of Iran and Iran by the threat of blocking the Strait can reduce the pressure of the sanctions to some extent.

Second: The study of the details of the imports of Iran from the countries of the Persian Gulf cooperation council reveals that the Persian Gulf cooperation council provide $7 / 7$ billion dollars that is $25 \%$ of the import needs of 
Iran that $32 \%$ of that consists of capital goods, around $31 \%$ of them are intermediate good, more that $21 \%$ raw material and less that $16 \%$ are consumer goods. Generally, in recent years more than 26 billion dollars of Imports to Iran from the world consisted of capital and consumer goods that the Persian Gulf cooperation council provides $4 / 5$ billion dollars of that. These figures show the significance of this council in providing the required capital and intermediate goods for the industries of Iran (Sagheb, 2008, 177).

Third: The final issue in this respect is that of lack of willingness of the members of the Persian Gulf cooperation council to do business with Iran and preference to do business with the West world. Although in November of 1991 Hashemi Rafsanjani the ruling president proposed the establishment of a regional common market which would lead to common technical and economic cooperation between Iran and the members of the Persian Gulf cooperation council (Rakel, 2008, 158) but no positive answer was received in this respect from the regional countries and in contrast the mutual treatment of cooperation between Europe and the member countries of the Persian Gulf cooperation council which had been signed in 1988 by the sides was put into action in 1990 . Economic cooperation by establishing specialized work groups in the filed of energy, environment, and industry is pursued although the results of such actions are quite various and consist of establishing conferences and conferences up to the decision to create the Jabil trade zone in Saudi Arabia because of the problems in this respect the countries of the region in order to prepare the required foundations of signing trade contracts with European Union made an agreement to establish a customs union among themselves. Finally, after the council action in this respect the technical procedures of the aforementioned negotiations to establish a free trade agreement were finalized in January 2007 (Sagheb, 2008, 165).

C) Cultural. Culture and cultural issues are among the factors which can influence the relation in terms of establishing cooperation foundations within economic and political foundation. Since culture includes language, religion, race and tribe in between Islamic Republic of Iran and the countries of the Persian Gulf the following issues are considerable:

1- The concept of export of Islamic revolution caused lots of panic especially among the neighboring countries of Iran (Saghafi Ameri, 2009, 136) this fact cause that during the eight-year war between Iran and Iraq all of the countries of Persian Gulf support Iraq (Katzman, 2006). Also the Arab countries of the region have been in terror of the influence of Iran especially in terms of the activities by Iran in their inside countries. \{Persian\} Gulf States with Shia populations particularly Bahrain have the feeling of susceptibility from interference by Iran (Dassa Kay and Wehery, 2009, 38). The heads of the countries of Persian Gulf blame Iran for supporting radical Shias and consequently any relation with Iran from the vantage point of radical Sunnis of the Persian Gulf is considered as a threat (Byman and other, 2001, 75). The ideological nature of the Iranian culture from these countries' perspective means that when they are talking about Iranian culture Islamic revolution or the export of revolution or the issue of Shia comes into their minds which tend to cool the mutual relation. As far as King Abdullah talks of Shia crescent or that Hosni Mobarak says that the allegiance of the regional Shia Muslims is more to Iran compared to that of their corresponding countries. That is they feel that the Shia identity is prior over national identity. This goes as far as that during the 33-day war one of the Saudi mufti decrees that praying for the victory of the Hezbollah is religiously unlawful while the opposite side is Israel and Zionists. Therefore, in his opinion the danger of Shia is more than that of Zionists (Dehghani Firoozabadi, 2008, 30b)

2- The other challenge is to get control of the Muslim world leadership. Although the power and ability of Saudi Arabia originates from its ability to influence the world oil market and its role as the producer of black gold but this country by the use of this unique position has tried to reinforce other aspects of its power (political, economic, and military) and by the use of the position of the sacred shrines of the world of Islam has planned its diplomatic and cultural efforts to get the leadership of the world of Islam on the basis of these two major sacred places (Sadeghi and Ahmadian, 2011, 140). However after the war of Iraq against Iran and the presidency of Rafsanjani, Islamic Republic of Iran had a chance that by the use of more expansive range of political choices compared with that of the pre-war period apply a more realistic position. Apparently this current is represented within the framework of Umm Al-Qura doctrine of the world of Islam. Umm Al-Qura doctrine is in fact the new format of the Islamic Republic of Iran fundamentalism that the same as Ottoman Empire intends to take control of the world of Islam and expand Islam from Tehran. Mohammad Javad Larijani the deputy foreign minister of that presidency in terms of defining the Umm Al-Qura doctrine states that: "the first issue is our position in the world of Islam. That is Iran should not be limited to the borders, it does not mean that we intend to occupy other countries but our position in the world of Islam is not defined by geographic borders...we need to define our diplomacy and policy that to be in coordination with our position in the world of Islam. We have a great role in the world of Islam no other country can lead the world of Islam and this is a historic great position" (Azghandi, 2006, 34, 35). 


\section{Eastern Area: Indian Subcontinent and Afghanistan}

The South East part of Iran has always been under the attention thanks to special geographic and climatic position, proximity with Hirmand and Hamun rivers, neighborhood with Afghanistan as a country which has long been considered by the great powers of the world and overlooking to the South and Oman Sea and Indian Ocean. Also the access to the International free waters outside the Strait of Hormuz and the opportunity of communicating with the countries of the West Asia, India, Arab Sheik-ruled sates and the African markets has intensified the significance of this area (Khalili et al, 2012, 88). On the other hand this issue is considerable that Systan and Baloochestan province which is the largest province of Iran is located at this area. Sytan and Baloochestan has 1100 kilometers borderline with Pakistan and Afghanistan and 300 kilometers of sea border with Oman sea and because of the location at transit and strategic position has a lot of importance (Ahmadi et al, 1390, 23). In this respect India, Pakistan, and Afghanistan have strategic importance for Iran in terms of foreign policy. Therefore, in the following part a brief study of these three countries and opportunities and challenges of Islamic Republic of Iran in relation with them at three political, economic and cultural parts would be analyses.

\section{The Political, Economic, and Cultural Importance of the Eastern Area}

A) Political. From political perspective the Eastern and South Eastern borders of the country which is located close to the Subcontinent and Afghanistan has always witnessed tension and insecurity which has always originated from outside the borders. In this respect issues such as the political dependence of India to the United States of America, smuggling drugs from the borders of Pakistan and Afghanistan, extremists movements and inspiring the tribes at the Eastern border and ultimately war and volatility in Afghanistan has always caused threats to the security of Islamic Republic of Iran.

The fall of Soviet and the end of cold war caused that India in addition to threats such as the influence of Pakistan in Afghanistan and the spread of Islam which by the assistance and coordination of Arabs on the issue of Keshmir has happened and was confronted with issues such as loss of long-term military weapons producer i.e. Soviet Russia and also the access to the newly independent countries of middle east (Berman, 2011, Nighqujam and Inbar, 2002). This fact intensified the feeling of necessity by India to establish with Iran. Particularly, by considering the need of India in terms of energy because of increasingly improving industry and lack of access to the Middle East through Afghanistan because of the problems with Pakistan and also insecurity in Afghanistan the path through Iran seems to be the best choice. In This respect attempts have been made to expand relations to cooperate in terms of oil projects in Iran an also establishing energy transport lines. But the occurrence of the $11^{\text {th }}$ of September event this direction experienced changes.

After the $11^{\text {th }}$ of September event and the occurrence of terrorist attacks in Bumbai America found out that it needs to revise its policy concerning this part of the world and the Afghan and Pakistan Muslims and the impact of extremism on international peace and security drew the attention of America towards South Asia (Sazmand et al, 2015, 56). These issues made America make attempts to make closer relations with India and as a result of these relations the relation between Iran and India cooled down so that in the final days of 2010 the Indian government in an action in line with that of America joined the line of countries imposing sanctions against Iran (Sazman et al., 2015, 71). According to the law of peaceful nuclear energy cooperation of India-America known as HIDE India should prevent Iran from nuclear activities or dissuade or if necessary sanction Iran or prevent the attempts made by this country to obtain mass destruction weapons (Sadjadpoor and GHahroodi, 1390, 253). In addition to that India rejected the request of Iran to launch a satellite which failed the hope of Iran to cooperate in space technology (Inbar and Nighqujam, 2011)

Among the significant issues in the relationship between India and Iran is the attempts made by this country to influence Afghanistan. Although the prevention of spread of extremist Islam by the assistance of Pakistan is among the main goals of India in Afghanistan but the necessity of getting access to the energy reserves of the Middle East has made India to double its efforts to expand its influence on Afghanistan \{which historically for a long period of time has been under the influence of Iranian culture\},(Pant, 2011, 39). The Indian government has tried to encourage Afghanistan to join the SARK group so that facilitate the economic development of the country by the free transport of goods by the borders of the region. However the membership of Afghanistan in South Asia SARK enables easier access to the central Asia (Pant, 2011, 33).

The relationship between Iran and Pakistan has also experienced several fluctuations. But generally, two principle aspects are very significant in this respect. First, the death of a number of Iranians in the Eastern and South Eastern borders of the country shows that the organizations and arrangements of terrorist movements are done from inside Pakistan territory and the terrorists and the interfering agents are able to pass through the borders of Pakistan into Iran and return once again (Ahmadi poor et al, 2012, 33). Second, until, 1998, Russia 
was the only atomic neighbor of Iran after this year the Southern Asia had two nuclear countries and the number of nuclear neighbors of Iran increased. Therefore, East of Iran became a nuclear area (Sadjad poor and Ghahroodi, 2012, 248). The support of Pakistan from the peaceful nuclear program of Islamic Republic of Iran can be analyzed from this vantage point that after finalizing the nuclear issue of Iran the next topic on the United Nation's agenda would be the non-proliferation and disarmament of Pakistan, India and Israel. Generally Iran can be concerned about arms race in subcontinent and particularly Pakistan. A: Tests, researches, and nuclear explosions of Pakistan happen near Iranian border in Baloochestan Province. B: The establishment of an extremist quasi-Taliban fundamentalist government with high nuclear capability is dangerous and threatening for Iran but the more serious threat is the stealing of Plutonium or small bombs and portable nuclear of this country by organizations and the influential fundamentalist groups. C: The position of Pakistan as a nuclear power against Iran is more powerful and stable than before (Khalili et al, 2014).

The other Eastern neighbor of Iran is Afghanistan. Afghanistan is a country combined from different tribes which only because of nineteenth century British strategy of the possible unity of Iran and Russia was established. In fact, at that period of time Britain created this country on the basis of strategic and geo-politic needs of India (Keyvan Hosseini, 1999, 54). Problems such as insecurity and instability in Afghanistan such as planting and smuggling drugs are among the issues that Iran is faced with in the case of Afghanistan. The occupation of this country by Soviet and then dispatching forces by the United Nations to confront the terrorists after the $11^{\text {th }}$ of September have made lots of the Afghan to migrate to Iran. The flood of Afghan migrants to Iran from the attack of Soviet to this country in 1979 and after that during the 2001 war of Afghanistan has always been on the rise. According to the statistics 9-11 percent of the Afghan population lives in Iran. Also Antonio Marya Kusta the head of the fight against narcotics of the United Nations office has described the Afghanistan Pakistan border area as the most active area of drugs smuggling in the world. Goods and drug smuggling are the issues that three countries of Iran, Afghanistan and Pakistan need a constructive and close cooperation to overcome (Vaezi, 2010, 33).

B: Economic. The eastern and South eastern region of Iran have high capabilities in terms of economy and the Sytan and Baloochestan which is the neighboring province with this area in terms of trade exchanges is considered as the most important passages of the old world (silk road) and has lost of potentials in terms of trade (Khalisli et al., 2012, 108). Generally, the Geopolitical capacities of the South east of Iran can be defined as follows: 1) Communicational capacities 1-1: transportation a: marine: Since of the major influential factors concerning the price of the goods is that of transportation cost then the cost of transportation is the principal factor in determining the type of transportation instrument. This fact encourages the use of marine transportation as the cheapest and the highest capacity choice in fact the cost of transporting cargo with plane is about 480 times more and by truck 150 times more and by train 22 times more and by pipeline 7 times more and by small ships 5/5 tomes more than the transportation by large ships such as tankers and super tankers b: Road transportation: The south east road network of Iran is only a north-south network which lack sufficient and apposite development and expansion. c: Rail transportation: The establishment of rail corridors and its attachment to the neighboring countries and the Iranian ports are among the strategic economic programs which have high final capacity and would have high rate of national development because the expansion of the communication network at eastern axis would bring at least annually 10 billion dollars for the country. But neglecting this project would transfer it to Pakistan by the establishment of rail at Guadr this golden opportunity would be prevented from Iranians. d: air communication: South east of Iran despite having apposite location to receive the airplanes of the other countries for landing and using the services and the consequential revenues are transferred to other countries such as the UAE and Pakistan which have international airports with apposite services and facilities. 2) Alternative for the relative exit of Ian from the Strait of Hormuz: Iran is the most dependent country to the strait of Hormuz and $100 \%$ of the fossil energy and $80 \%$ of export and import of Iran is done through the aforementioned passage. Therefore, under the marine blockade situation and the threat of the Strait of Hormuz security Iran would be highly susceptible. 3) Goods transit and the connection of Afghanistan the central Asia and Russia would have access to the free seas and other parts of the world 4) Access to the India ocean and free seas with various potentials: which has international and political potentials, economic potential, and changing Iran to a marine power (Hafez Nia and Romina 2006, 7-11). 5- Chahbahar free trade region: This area is located on the path of international water passages and as a bridge among the ECO organization and member countries act as the export production and exchange and transportation (Khalili et al., 2012, 109). Chabahar port directly or indirectly is located on the path of several key international routes and has the capacity to become one of the most strategic transit positions. Chabahar also has high rate of capacity to connect the developing South Asia (India), Persian Gulf (Dubai), and Middle East and Afghanistan and the transportation of goods from India to Afghanistan and Middle East has been facilitated (Niyakooie and Bahrami Moghaddam, 
2014, 137).

In terms of India it need to be mentioned that India under the framework of looking towards the west and to the north which is based on the economy and energy diplomacy looks at Iran as an important partner. In terms of the communicational corridors Iran has facilitated the access of India to the markets of Afghanistan and Middle East. Iran can also provide the access of India to Caucuses and Europe. In this regard Iran and India cooperate in terms of marine, land and train rails projects cooperate in a mutual way. In this case Chabahar port and the pertinent routes to it and the north-south corridor are among the most significant areas of cooperation between Iran and India in terms of goods transportation (Niyakooi and Bahrami mogaddam, 2014, 131).

Iran and India have made attempts to construct the north-south corridor by the help of Russia. The two countries have signed an agreement titled north-south transportation corridor ${ }^{1}$ in Saint Petersborgh in September 2000 and as part of the agreement India agreed to assist Iran in terms of expanding Chabahar port (Balooch, 2009). This corridor causes fall of the transportation cost and also it is considered a rival for the Suez Canal and reduces the cost of transportation up to $30 \%$ and the time of transportation to Europe to one third (Amir Ahmadian, 2005, 17 and 18).

The economic relation between Iran and Pakistan is run through the common economic commission of Iran and Pakistan ${ }^{1}$ which was established in 1986. The most important part of the economic relation between the two countries is the peace pipe (Javadi Arjmand et al, 2013,69) A preferential trade agreement was signed between the two countries in the September of 2006 but the trade could not be practiced because of the sanctions against Iran at an acceptable level (Malik, 2014). The discharge of foreign forces from Afghanistan has improved the relationship between Iran and Pakistan to a large extent and Navaz Sharif visited Iran in 2014 while the last visit was in 1999. Pakistan needs to stabilize its Middle East policy when the region is in crisis and only the tendency towards Iran can fulfill this necessity (Malik 2014).

In the case of Afghanistan it is considerable that although the "Bon agreement" planned the formation of national and democratic government under the protection of international community in Afghanistan, "Tokyo agreement" planned the reconstruction of this country. Iran which before and after the Islamic revolution has been one of the significant providers of funds for development programs of Afghanistan by attending at Tokyo conference and promising 560 million dollars loan to Afghanistan which was decided that 250 million dollars of that be gratuitous and 250 million dollars as export credit and 60 million dollars of it as the gratuitous loan of the humanitarian foundations be paid over five years time (Abbasi and Ranjbardar, 2012, 198). Generally Afghanistan can be looked at as a source of wealth and providing security. Some issues can highlight this process: 1- nowadays any country to take hold of the economic power mostly in one area consider preparing foundations in the corresponding area. In terms of economic regionalism in addition to factors such as cultural and political connections membership in unions and regional contracts and index such as the presence of a country in the development of economic and trade foundations of the neighboring country is among the factors which expand economic nexuses. This process in addition to the reduction of production expenses increases the willingness of the manufactured goods by the loan receiving country which will increase the finance opportunities at world level. 2- Afghanistan's consumption market is very important. At the present time Afghanistan does not produce anything. Its production is limited to farming and cattle produces and provides all of its needs by importing. 3The important economic and even agricultural Afghanistan at eastern, northern and southern regions and its western areas which share the same border line does not have a developed economy. Since the Iranian development projects are focused in these areas undoubtedly the development of them would impact the economic development of both countries. 4- Afghanistan can be a center for Iranian export to middle Asia such as Tajikestan. 5- The unique position of Iran in the area and the start of reconstruction and the return of migrants the linguistic commonalities and the long-term attendance of the Afghan migrants in Iran and their conversion to Iranian goods and taste are among the apposite factors which can improve the economic relation between the countries (Abbasi, Ranjbardar, 2012, 215).

C: Cultural. Iran is among the countries with variety of religion, creed, tribe, language and culture. Among them Iran compared with 200 countries or world political-geographic unit has relatively the highest diversity (Modishane chi 2002, 26) and the important issue in this respect is that the variety of tribe, language and religion are among the features of India, Pakistan and Afghanistan (Ahmadi poor et al, 29). The susceptibility of these countries in this region of Iran is evident and because of the Islamic and Persian language quality influences a large range of geography (Shafiei, 2014) within the cultural filed of all subcontinent countries and particularly Pakistan consider Iran as the civilization and cultural cradle (Javadi Arjmandi et al, 2013, 61). This issue even in relation with India because of the geography is far from Iran and is not part of the neighbors of Iran can be as an instance. By the conquest of India by Mahmood Gaznavi and the ruling of Iranian governors, Persian language 
was expanded over this land or entered this subcontinent at a large extent and gradually became one of the most important languages of India. Then by the vast immigration of scientists and scholars and artists and literary figures to the Muslim palace of India at sixth century Lahur became a center of distribution and expansion of Persian literature. Guri Turks who had conquered the Ghaznavi dynasty has a significant role in the expansion of Persian language. By the attack of Mogul to Iran which destroyed all foundations of civilizations in Iran there was no hope to keep the Iranian culture and the nationality and India became one of the most important safety havens of the Persian scientists, intelligentsia and writers and their vast presence at Indian court lead to the expansion of culture and Persian language in India and consequently we witnessed the spread of Iranian names and proverbs and rituals and ceremonies in India. Although by the direct and active presence of England in India the English language replaced the Persian language over a period of century but some of the people interested in Persian language valued the Persian language and continued their researches on literature and poetry of Persian language (Fallah, 2000, 137). After the independence of India and Pakistan and their political agents exchange with Iran, at Iranian and Pakistani and Indian Universities Indian language and Persian language departments were started and the pertinent professors kept on with their studies on literary and cultural activities. At the present time at 24 Universities of India Persian language is taught at BS, MA and PhD degrees and 16 religious schools teach Persian language (Fallah, 2010, 139). Although in Pakistan the influences of Persian language is conspicuous at every where but it has more significance at western provinces. The national anthem is written in Persian by Eghbal Lahuru. This fact along with the great religion of Islam influences the relation between Iran and Pakistan as an identity factor (Javadi Arjmandi et al, 2013,6). Despite that Pakistan is highly influenced by the creed of (Vahhabiyat) to a large extent. Long standing tribal/national competitions in an attempt to export cultural values and spread the value systems and protect those of the same religion are among the activities made by this country. In fact the expansion of ideological forces range in pursuit of opponents outside the borders and ideological control of the region are among part of the results of political-cultural competitions with the neighbors (Khalili et al, 2014, 100). Impractical relations of policy and religion fields of Muslim groups in Pakistan in addition to Vahhabiyat ideas and the incapability of the state in practicing the security have lead to the expansion of anti-Shia and anti-Iran ideas under the framework of social forces of this country within the framework of different threats against national security of Iran. So that some of the analysts consider the most significant cause of dispute between Iran and Pakistan the tribal and Shia Sunni identity benefits and interests (Ghafuri, 2015, 95) which is also visible in terms of Afghanistan because by the occupation of Afghanistan by the Soviet in 1979 Iran protected the Tajik tribe and Pakistan supported Pashtons. Tajiks are Shia and were closer to Iran and Pashtoons are Sunni who supported Pakistan (Fahad, 2014).

Afghanistan in the memory of the contemporary history has always been considered as the inseparable territory of Iran (Keyvan Hosseini, 1999, 43). As a confirmation of this fact it should be mentioned that the Arabs who had gone to Afghanistan to fight mostly made use of the old name of "Khorasan" which is derived from the one of the largest provinces of Iran (Williams, 2011, 218). The Shia in Afghanistan constitute one third of the population in Afghanistan and in terms of the tribal and racial identity are divided into three main groups of Hazare, Sadat, and Ghezelbashha (Keyvan Hosseini, 1999, 51). But what is considerable in terms of Afghanistan is that large number of Afghans can speak Persian and are bilinguals (Pashto and Persian). Tajik tribe speaks in Persian with Dari dialect and the population of Velayat, Farah, Zabol, Helmand to the west of Afghanistan generally speak in Persian or at least understand Persian language only at tribal parts the Pashtoo language is popular. Turk tribes such as Uzbaks are familiar with Persian language to some extent. But the fact of the number of the number of Persian language speakers is not the point of significance but their almost higher culture compared to that of others can determine the power equation in Afghanistan. Persian language in fact has been the writing and official language of Afghanistan and the efforts to replace it by Pashto language has not been successful. The control of Tajiks over Kabul has provided Persian language with an apposite position (Molazehi 2006, 125).

\section{Northern Area: Middle East and Caucasus}

The fall of the Soviet and the end of cold war lead to vast geo-political changes over the north of Iran. On the one hand the appearance of eight Euro-Asian central countries and on the other hand change of the control over the coasts of Caspian Sea from two countries of Iran and Russia to five countries of Iran and Russia and Azerbaijan ,Turkmenistan and Kazakhstan (Parvizi Amineh, 2003). This region which consist of two parts of central Asia and Caucasus consist of Iranian, Turk, Russian, Turkmen, Uzbek, Ghorji, Armenian, and in terms of religion consist of Sunni, Shia and Orthodox Christianity (Naghib Zadeh, 1997, 77). The most agreed upon definition of central Asia refers to five countries, Turkmenstan, Kakhzkestan, Caucasus, Uzbekistan which is located to the east of Caspian Sea and ends up in Iran from South and Afghanistan and to the north Russia and to 
the east China (Faraji Rad and Kheiri, 2014, 92). Because of geographic position the winters of this area is very hard with high mountainous regions dangerous to pass and with lot of dry and barren areas. This geographic condition means higher cost of transportation, communication, transit and longer time of goods delivery to the international markets and for the industries less access to the information and technology by communicating with the sellers and ultra-border markets accompany (Shahabi and Sheykholeslami, 2011, a, 83). The closest point of the central Asia countries to the sea is around 2000 kilometers from the Persian Gulf and 5000 from the Pacific and even the closed sea of Caspian. Only two countries of Caucasus and Turkmenistan of these five countries are overlooking to the sea. Therefore, these countries from geo-politic perspective require a strategic influence on each other and can not be needless of that. Because in other cases they have ruled on the death decree and seclusion of themselves (Alsamarani, 2005, 318)

Southern Caucasus because of its geo-politic position is a critical region particularly from the side that it is the passage in between Asia and Europe. Hegemony powers have always made use of this place as a means of influencing the neighboring areas. In the past the Ottoman and Iran empires and in the present time Russia and USA are engaged in such a strategy (Hass and others 2009). Turkemenchay agreement in 1828 lead to the loss of Iranian lands and its union to the Russian empire divisions which are named as Armina, Ghorjistan, and Azerbaijan anyway, Iranians consider Caucasus as the close borders to them and consider that political, economic and diplomatic priority is their natural right (Rubin, 2012).

\section{Cultural, Economic and Political Significance of the Northern Region}

A: Political. The fall of USSR led to the division of the neighboring countries of the North of Iran from one country to several countries and this fact by considering the diversity of tribes and languages that live on the opposite sides of the borderline could lead to instability and tensions in the region. Considering this fact and attending the newly independent countries none of them can alone or even by making union among themselves can not overcome the military and political vacuum caused by the fall of USSR which prepare the bases for tensions and disputes and the presence of foreigners from political perspective there is no tension-rising causes in between Tehran and the capitals of the central Asia countries and except for the Hirmand river water Iran has got no other problem with them in terms of politics, land and history (Taeb, 2010, 57). But this issue is a bit different in terms of Caucasus region because Iran and Azerbaijan has had a number of disputes. Distrust of the Azerbaijan officials has lead to the blaming of Iran in terms of spying of Tehran against Baku. Azerbaijan blame Iran of causing tension among Shia communities in Azerbaijan and supporting the extremists in Nardan village. Even a number of the youths by the tile of (Saeed group) without any document were sentenced for espionage for Iran on $5^{\text {th }}$ of September 1997 who were captured (Minaie and Asgari 2014, 74). Azerbaijani is another country that after Iran, Iraq, Bahrain has the majority of Shia twelve Imams (Rubin, 2012). And this fact was also considerable in terms of the use of the Caspian Sea resources. The height of the confrontation of Iran and Azerbaijan happened in 2001 over the use of Caspian Sea resources. So that in July 2001, Iran threatened Azerbaijan that unless Azerbaijan does not withdraw the oil search and extraction ships back from the Alborz oil field it would make use of force. This dispute even continued up to the year 2002. In February and November of 2007 Iranian air forces entered the Republic of Azerbaijan air territory (Dehgani, Firuzabadi, 2009, 213). Despite, these disputes Azerbaijan supported the peaceful right of Iran to make use of peaceful nuclear technology and has repeatedly repeated that he would refrain from joining the anti-Iranian alliance (Sadegh-Zade, 2008, 39). Among other features of this region from political perspective is the proximity with China as the emerging power Iran with the developing position and Russia with its regional ambitious is still the only non-western power of the region which has highlighted the geo-political and geo-strategic significance of the region for the west particularly USA (Ataiee and Shiebani, 2012, 135). The foreign policy and priorities of America in central Asia can be explained as follows: 1- Preventing the Russian power revival 2- Harnessing Islam with political tendencies 3- Harnessing Islamic Republic of Iran 4- Economic interests particularly energy 5- Preventing the spread of nuclear weapons 6- Presenting a model of development in proportion with its plans for the region (Faraji rad and Kheiry 2014, 109).

B: Economic. Central Asia and Caucasus that after the fall lost their organized and organic relations under a complex of single economy which has been lost today in providing their needs and to present their products require new economic complements. Also these countries in order to benefit from their resources and facilities require foreign capital and investment for the same reason attracting the industrial-economic cooperation are in competition with each other (Alizadeh, 2010, 278). Apart from raw oil and natural gas these countries are at optimal condition in terms of agricultural products such as cotton, minerals such as gold, copper, aluminum and iron (Shahabi and Sheikholeslami, 2011, a, 83).

By considering the factor of lack of access of central Asian countries and Caucuses to the open seas and the 
strategic position of Islamic Republic of Iran is the best choice to get out of the geographic dead end and facilitate their access to the open seas. Under the general estimations of the Islamic Republic of Iran which is based on the fact that although the independence of these countries lead to the rise of the number of countries supplying the energy to the international market but these countries because of lack of access to the open seas in order to transport the energy products they need Iran strategically. By considering the fact that the territory of Iran in transportation discussion of goods and passengers and its general definition of power, gas, oil, and water for the central Asia countries can be the best choice. Therefore, Islamic Republic of Iran has been able to prioritize these activities by planning the North-South corridor to expand the relations in terms of transportation sector (Rahmani Movahed, 2007, 304). For the countries of central Asia the geographic position of Iran has a significant role for their economic development. This issue is not overlooked by the Iranian government which has signed multi-lateral gas-lines which transfer the gas from these countries to Europe. Therefore, Iran presents them a stable regime in opposite to that of Afghanistan and Caucuses which are instable and bereft of development opportunities (Kashgari, 2011). In this respect Iran has finalized a umber of activities. In 1996 Bandar Abbas-Tajan the railroad between Turkmenestan and other Middle East and Iran passage was opened up (Bayman and others, 2001, 80). By the completion of Mashad-Sarakhs-Tajan in 1996 central Asia countries were connected to Iran and their reliance on the Russian railroad and road systems became reduced (Balooch, 2009). Eastern Caspian railroad was opened up by the presence of three presidents of Iran, Turkmenistan and Kazakhstan was operated which connect central Asia and Caucuses to the open seas (2015/9/12www.farsnews.com news code 13930 12000428).

C: Cultural. More than one thousand years of cultural and political influence among the Central Asia and Caucuses people is a winner card which can reinforce the role of Iran in the region. Although Turkish language is the official and state language of the central government but the cultural language up to the Soviet era was Persian language. Most of the central Asian people are traditionally trained in both Turkish and Persian. Besides that the geographic proximity and the long term common life experience with regional nations has caused that Iranian culture is considered as the natural dominant culture of the region in central Asia. The cities of this area such as Bokhara, Samarghand, Balkh, Marv, KHive, Kharazm are considered as the Iranian science and cultural centers and have great position in Persian literature. All of these factors confirm a long standing cultural influence of Iran in central Asia and Caucuses whose revival and adaptation with contemporary requirements can significantly impact the optimal role of Iran in the region (Noruzi, 2001, 135).

Central Asia and Caucuses as the civilization hub of Iran can facilitate the influence of this country in the region but the presence of weak diplomacy of Iran and foreign policy such as aggressive diplomacy with America exist in this way (Haj Yusefi , 2009, 95). The same as the other regional areas the presence of tribe on the borderlines of countries creates concern. Tehran is afraid that the emergence of tribal identity creates the same call in Iran for similar activities particularly by the presence of these tribes and minorities at the border line. Therefore, Iran refrains from opportunities and activities of these groups in the region so that in his visit with Russia Hashemi Rafsanjani suggested to keep Azerbaijan within the Russia. Iran in contrast to Turkey reluctantly accepted the fall of Russia and also in Persian speaking Tajikestan Iran presented a peace plan that all sides were included despite the presence of cultural and Islamic movement power Iran has directly cooperated with the Christian Armynians and supported them in the fight against the Shia in Azerbaijan and during the fight of Russia with the Musilms of Chechen Iran considered it as a local and central issue (Byman and others 2001, 78). Despite the presence of various tribes and racial groups in central Asia and Caucuses religious believes have approached people to a large extent. The history of these cultural and historic nexuses goes back to previous centuries and the rule of Muslims over the central Asia and Caucuses. These regions along with the west limit of the Asia and Middle East have common cultural heritage which differentiates them from other areas. Iranian-Turkish identity has a considerable dimension in these countries (Koolaie, 2001, 257).

\section{Conclusion}

Although Persian Gulf has provided a superior position for Islamic Republic of Iran from economic perspective in terms of policy making but differences in terms of culture, religion and race and extreme dependence of the regional countries to the west on the one hand and the expansive propaganda by America concerning Iran-phobia and Islamic revolution to seclude Iran on the other hand has caused inapposite relation among them and always accompanies tension. This is while the eastern, south eastern and northern parts of the country have been under the influence of Iranian culture and provide the foreign policy making of Islamic Republic of Iran with more opportunities to expand relation it is axiomatic that given the facilities provided by these regions the general policy making should be available for having access to national goals. In general these regions have the following features: 
1) In terms of the energy transit the position of Iran provide the central Asia and Caucuses to transfer energy to the Persian Gulf that can provide Iran with revenues and increase the rate of employment in the country which requires the country's activities in terms of building the infrastructure of transportation of the country.

2) Critical need of energy by India and Pakistan and also attention to the fact that the only way India can connect to the central Asia because of the instability and insecurity in Afghanistan and Pakistan is only possible through Iran and has increased the relation between Iran and India despite the unwillingness of America. By this description and in spite of common cultural backgrounds between the sides they can experience expansive mutual relations.

3) The dependence of Iran in terms of economy to the oil revenues has caused that Iran becomes highly dependent on the Strait of Hormuz that this issue that can impose huge sanction against Iran by the use of international system might be misused. According to this Iran should make attempts to have alternatives in this respect. The development of port in the north and south east can both reduce the dependence of Iran to the Strait of Hormuz and provide the requirements to decrease the impact of sanctions.

\section{References}

Abbas, M. (2001). analysis of the Islamic Republic of Iran and Persain Gulf cooperation council on triple islands third year fourth No.

Abbasi, E., \& Ranjbar, M. (2012). financial loans of Iran to Afghanistan purposes and economic impact of that third year No.three.

Alsamarani, A. (2004). the central Asia: Geographic position and strategic significance. Eleventh International conference of the central Asia and Caucuses political and international studies office.

Amir Ahmadiyan, B. (2003). North south corridor and its significance in unity of the region seasonal magazine of the central Asia and Caucuses No. 41.

Amir, A. (2010). study of the foreign politics in the document of the horizon of Islamic Republic of Iran Yas strategy No.19.

Azgandi, A. (2005). Forieng policy of Islamic Republic of Iran (3rd ed.).

Bachevich, A., \& Inbar, E. (2003). The Golf War of 1991 Reconsidered. London: Portland.

Byman, D. et al. (2001). Iran Security Policy in The Post- Revulotionary Era Retrieved from http://www.rand.org/pubs/monograph.reports/mr1320.html

Dassa kay, D., \& Wehrey, F. (2009). Containing Iran?: Avoiding a Two -Dimensional Strategy in a Four Dimensional Regional. The Washington Quarterly.

Dehgani, F., \& Jalal, S. (2007). national resources of the Islamic Republic of Iran politics seasonal law science and law faculty period 39 .

Fahad, Sh. (2014). Pakistan and Its Relationship With Iran And Saudi Arabia. Retrieved from www.pakistankakhudahafiz.com/report-analysis/depth-analysis-pakistan-relationship-iran-saudi-arabia/

Hafez niya, M., \& Romina, Eb. (2005). study of the geopolitic capacities of south east coasts of Iran geography and development journal autumn and winter 5-21.

Hafezniya, M. R. (1989). political role and military role of the Strait of Hormuz, Islam guard magazine, $10^{\text {th }}$ year 11 pp.45-46.

Haji Yosefi, A. M. (2009). Shia crescent opportunities and threats for Islamic republic of Iran, Arabs, and America, political science seasonal No.1.

Hass, M. et al. (2009). Geo- Strategy in the South Caucasus Power Play and Energy Security of States and Organisation. Clingendael Institute. Retrieved from http://www.clingendael.nl

Hoseyne Porpoyan, R. et al. (2011). geopolitical statement power relations in subcontinent region after $11^{\text {th }}$ of September events 2001 geopolitical journal eighth year, No. fall pp. 1-34.

Inbar, E., \& Singh Ninghqujam, A. (2011). Indo-Israel Defense Cooperation in The Twenty-First Century. By Global Research in International Affairs Center December 22. Retrieved from www.rubincenter.org/.../indo-israeli-defense-cooperation-in-the-twenty-first-century/

Javadi Argmandi et al. (2012). neo-strategic analysis of the relations between Iran and Pakistan with an emphasis on security factor subcontinent seasonal studies Systan and Baloochestan University fourth year No.12. 
Kashgari, T. K. (2011). Understanding Iran: Between Central Asia and the Gulf Cooperation Council. Retrieved from www.studentplus.com/articles/505/2/understanding-iran

Keyvan, H., \& Seyyed, A. (1999). foreign policy of the Islamic Republic of Iran central Asia and Caucuses No22.

Khalili Mohsen. (2013). the nexus between geopolitics and foreign policy seasonal studies Systan and Baloochestan University fourth year fourth year No.17 winter pp.95-126.

Khalili, M. et al. (2010). requirements of geoeconomics of south east region development of Iran foreign relations seasonal, third year fourth No. winter pp. 81-124.

Mahmod, G. (2015). analysis of the state and community of Pakistan against the security of Iran sixth year spring pp.89-116.

Malik, A. R. (2014) A New Era in Pak-Iran Ties? Retrieved from www.pakistantoday.com.pk/2014/05/15/comment/pakistans-relations-with-iran/

Minaiee, HOSSEIN, Asgari, Mahmood. (2014). Iran and Azerbaijan optimal border line managemnt11th year No.41.

Morteza, F. (2010). status of culture in Persian language in subcontinent of India No.2.

Nozar, S. (2012). political and security equations in the south of Asia and its impact on the Islamic Republic of Iran. Retrieved from http://drshafie.blogfa.com/post-70.aspx

Nurmohammad, N. (2001). confrontation of Iran and Turkey central Asia third period No.29.

Parvizi Amineh, M. (2004). Caspian Energy: Available Alternative to the Persian Gulf? Eurasian Bulletin, $8(3 \& 4)$. Retrieved from www.eias.org/bulletin.htm

Pirmohammad, M. (2006). opportunities and threats ahead of Iran...Moaser international research and studies collected by Ali Abdolkhani.

Rahmani, M. M. (2006). 2006 conference of the Shanghay cooperation of the heads of states the central Asia and Caucuses political and international studies office 53 Report.

Rakel, E. P. (2008). The Iranian Plitical EliteT State and Society Relations and Foreign Policy Relations Since the Islamic Revolution. Retrieved from http://dare.uva.ni/document/104457

Ramezani, R. (2007). analytical framework of foreign policy of Islamic Republic of Iran Tehran Nei pub Fifth edition.

Rathmell, A et al. (2003). A New Persian Gulf Security System. Retrieved from www.RAND.ir

Reza, S. (2005). regionalism in global political geography changes of the conversions and the choices far beyond the political and economic No. 207-208 pp. 134-143.

Rubin, M. (2012). Iranian Influence in the South Caucasus and the Surrounding Region. Retrieved from www.aie.org/../2012../-iranian-influance-in-the-south-caucasusand-the-surrunding-152523983079.pdf

Sadat, A. R. (2006). Saudi Arabia green book Tehran political studies office of the foreign ministry.

Sadeghi, H., \& Ahmadian, H. (2011). Saudi Arabia from hegemony to regional leadership international foreign relations seasonal second year third No.

Sadeghzadeh, K. (2008, Winter). Iran,s Strategy in the Sought Caucasus. Caucasian International Affairs, 2(1).

Saeide, L. (2007). Persian Gulf and security of the Islamic Republic of Iran No. 48 and 49.

Sageb, H. (2007). study of the process of regional coordination among the Persian Gulf countries and its impact on Iran Persian Gulf Cooperation council research 28.

Saghafi Ameri, N. (2009). Iranian Foreign Policy: Concurence of Ideology and Pragmatism at The Iranian Revolution at 30. Retrieved from www.mideasti.org

Sajadpor, S. M. K., \& Karimi Gahrodi, M. (2011). nuclear competition between India and Pakistan and its consequences on the security of Islamic Republic of Iran strategic studies journal $14^{\text {th }}$ year No. four.

Sazmand, B. et al. (2014). power balance in between India and Pakistan under the current changes foreign policy journal sixth year No 1.

Soleyman poor, \& Daman pak. (2009). multiple role of regional arrangements in developing the economic diplomacy of Islamic Republic of Iran the central Asia and Caucuses political and international studies 
office second year, pp. 77-96.

Taeb, S. (2009). the necessity of evolution in the vantage point of Iran seasonal the central Asia and Caucuses, law and political studies second year No.5.

Taremi, K. (2007). perspectives and policies of Iran in terms of security of the Persian Gulf evolutions and failures law science and political science No.71.

Vaezi, M. (2008). Iran and threats of the instability in Afghanistan and Pakistan of crisis hub strategy in Asia research 26 .

Williams, B. G. (2011). On the Trail of the 'Lions of Islam':Foreign Fighters in Afghanistan and Pakistan,1980-2010. Published by Elsevier Limited on behalf of Foreign Policy Research Institute Spring.

\section{Copyrights}

Copyright for this article is retained by the author(s), with first publication rights granted to the journal.

This is an open-access article distributed under the terms and conditions of the Creative Commons Attribution license (http://creativecommons.org/licenses/by/3.0/). 